\title{
Occurrence and Distribution of Cave Dwelling Frogs of Peninsular India
}

\author{
Jayant Biswas \\ National Cave Research and Protection \\ Organization,Central Zone, Raipur \\ 492001, C.G., India.
}

Key words: Trgoglophilic frog, Cave frog, Western Ghats.

Abstract

The life in subterranean caves always needs a high degree of biological adaptability, due to its unusual ecosystem. The cave dwelling species usually get selected from preadapted biological traits for cave life. The cave dwelling tendencies in frog are very uncommon. Majority of reported cave frogs usually prefer cave for temporary shelter. In India, the biospeleological inventory is still in its primary stage. Till date no serious attempt has been taken to understand the cave dwelling habitat for any frog in India. Inspite of it, in India time to time various reports on natural histories of anurans reveal its cave dwelling tendencies. On the basis of personal observations and available literature in this report I have documented the occurrences and distributions of five cave dwelling frogs of India. Common biological traits from all the established cave frogs, which could be referred as preadapted for cave life, have been discussed. Further, the possible threats and IUCN status of each discussed species has been highlighted.

\section{Introduction}

Perpetual darkness, sporadic supply of food, near constant environmental conditions, and high $\mathrm{CO}_{2}$ levels are some of the common features of almost all known subterranean caves. Although all these together make caves inhospitable, some organisms successfully establish their populations inside them. Indeed a high degree of physiological adaptations, various behavioural adjustments and phenotypic variations are needed to establish a population permanently inside subterranean caves (Vandel, 1965; Gunn, 2004; Biswas, 2009, 2010). On the other hand, low predation pressure, high humidity, relatively stable geophysical factors, and easy availability of prey, are some of the extrinsic factors of the same cave that combine to attract many opportunistic species to exploit these habitats. Therefore it has been concluded that cave organisms belong to two categories; i) the animals that, once trapped accidentally

*Corresponding Author: jayant@cave-biology.org 


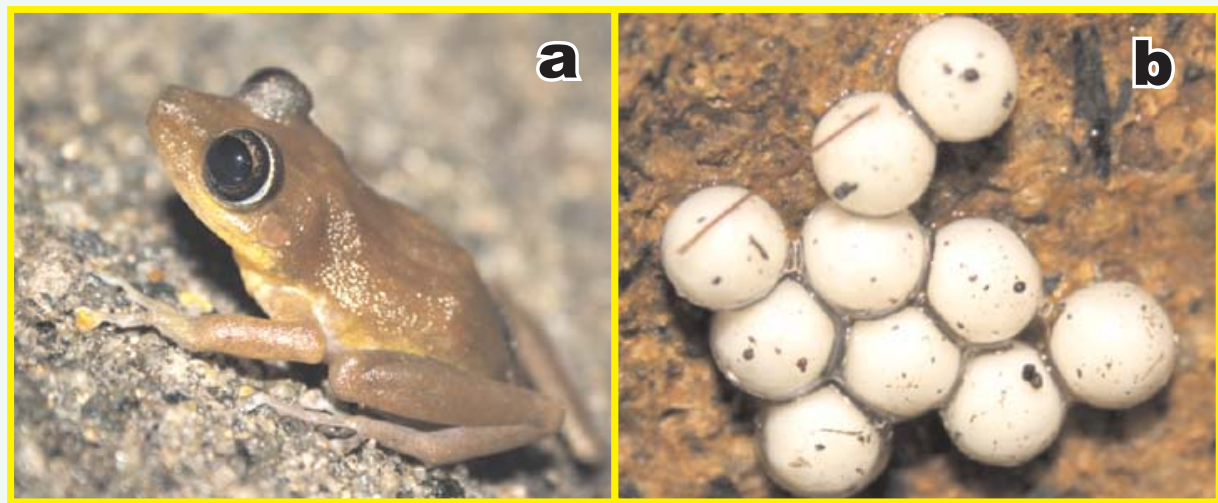

Fig. 1: a) Adult Eleutherodactylus cooki, b) eggs of E. cooki in the inner chamber of the cave

or intentionally get into any cave, successfully establish their race inside the cave, belong to the obligatory type; ii) the animals frequently visiting or almost settled inside the cave for feeding, roosting, hibernating, breeding etc. but have strong affinity towards its external environment belong to the opportunistic type.

The aff inity for cave life is always very bleak among frogs. Only a fractional percentage of anurans prefer cave life as their habitat (Black, 1973; Withers \& Edward, 1997; Rogowitz et al., 2001; Beard et al., 2003; Grismer et al., 2004; Barrio-amoros, 2006; Elliot, 2007). In general, frogs visit caves occasionally for temporary shelter against unfavorable external environmental conditions, such as summer drought or winter frost. Eleutherodactylus cooki Grant 1932, commonly known as the Puerto Rican Cave Dwelling Frog, is the most recognized cave frog. The species is endemic to Puerto Rico, restricted to the southern part of the island. The species is also known for its larger sized eyes. Earlier the species was reported to exist only in the caves and grottos, but now it has also been reported in rocky stream banks and plain forest areas covered with vegetation (Beard et al., 2003). As per Rogowitz et al. (2001) it is the only reported cave frog population which not only complete their life cycle but even reproduce entirely inside the cave (Fog. 1a,b).

Inside the cave, frogs commonly prefer the twilight /low light zones, which are characterized by high humidity and buffered temperature changes. Possibly it is to prevent the desiccation of their slimy skin, because in the twilight zone the body temperature of the amphibian corresponds directly to the ambient air temperature (Gunn, 2006). However, certain troglophilic frogs also occupy the deeper sectors of the caves in India. Petricolous frogs are usually seen to populate the cave habitats as their various morphological adaptations are helpful for survival inside the cave, viz., glandular finger tips, webs in fingers, camouflage colours etc. In India to date most cave frogs are reported from the Western Ghats (Valleys). In addition, a single species from the caves existing at Kanger Ghat National Park situated in the central part of India, and the caves of Jantia Hills of Meghalaya.

Herewith on the basis of the personal observations, literature survey and the reports obtained from various reliable sources, I am here presenting a brief biological account of the cave frogs that populate the caves of various regions in India. 


\section{Cave Frogs from the Western Ghats' Region:}

The Western Ghats (Valleys) are a mountain range that runs almost parallel to the western coast of the Indian peninsula. This region (along with Sri Lanka) is already declared a UNESCO World Heritage Site, as it is one of the eight "hottest hotspots" of biological diversity in the world (Myers et al., 2000). In India various frog species have been discovered from this region, among which the families Micrixalidae, Nasikabatrachidae and Ranixalidae are reported to be highly restricted to the Western Ghats and are each represented by only one genus, whereas the Family Nyctibatrachidae is endemic to both Western Ghats and Sri Lanka with the genus Nyctibatrachus endemic to the Western Ghats (Inger, 1999; Biju \& Bossuyt, 2003; Roelants et al., 2004; Aravind et al., 2004; Biju et al., 2011).

\section{Ranidae: Raninae}

Hydrophylax malabaricus Tschudi, 1838 Synonyms:

Rana malabarica

Hylarana malabarica

Hydrophylax malabaricus

Hylorana malabarica

Rana malabarica

Rana (Rana) malabarica

Rana (Hydrophylax) malabarica

Hydrophylax malabarica

Tschudi, 1838

Günther, 1859

Fitzinger, 1861

Günther, 1864

Boulenger, 1882

Boulenger, 1920

Dubois, 1992

(Frost, Grant, Faivovich,

Bain, Haas, Haddad, de

Sá, Channing, Moler,

Wilkinson, Donnellan,

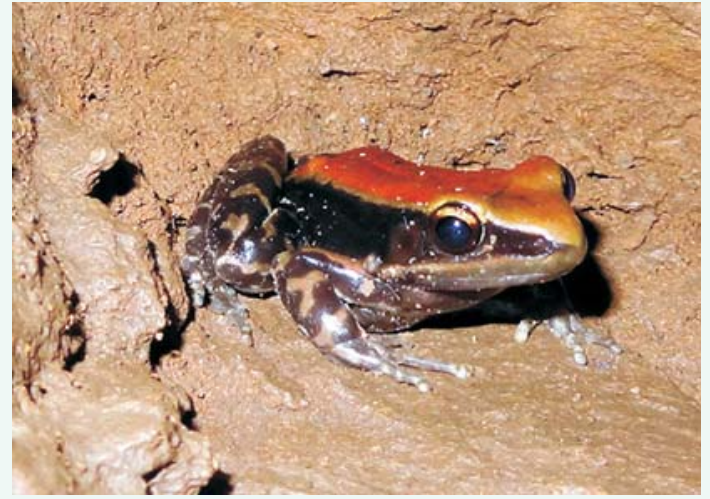

Fig. 2: Hydrophylax malabaricus

Raxworthy, Campbell, Blotto, Drewes, Nussbaum, Lynch, Green \& Wheeler, 2006)

Hylarana malabarica

(Che, Pang, Zhao, Wu, Zhao \& Zhang, 2007)

Hydrophylax malabaricus, commonly known as the fungoid frog. Orange camouflage colouring with black dots on dorsal surface; toes half webbed, short and swollen, and glandular finger tips are some of its most striking identifying characteristics (Fig. 2). It emits a very strong fungus like smell, possibly to protect itself from predator (McCann, 1946a). Previously the species was known to be highly restricted to the Western Ghats of India but later the same species was also reported from other hilly regions of the country (Daniel \& Sekar, 1963; Chandra \& Gajbe, 2005). Besides various named and unnamed caves of the Western Ghats, we have, over the past 20 years, personally observed this frog in twilight to deeper zones of the several subterranean caves of Kanger Valley National Park (in more than seventeen caves) throughout the year (Biswas, 2010; Biswas \& Shrotriya, 2011). Most of the caves of Kanger Ghat National Park have water ditches inside, but we have never seen any of these frogs inside such ditches. The populations were seen to increase during summer (January to April), and during the rainy season very limited numbers were apparent. This frog can be easily noticed in most of the subterranean caves lying in the Western Ghats of India. The very first available detailed report on this species was by Chari (1962), who 
reported its occurrence in stone cisterns at the Kanheri caves $\left(19^{\circ} 12^{\prime} 30^{\prime \prime} \mathrm{N} 72^{\circ} 54^{\prime} 23^{\prime \prime} \mathrm{E}\right)$ that exist in the same zone (Western Ghat). Chari (1962) also documented the occurrence of tadpoles of this species in the small water pockets in open epigean areas adjacent to such caves, which suggests, in spite of cave-adapted life, perhaps this frog prefers suitable external habitats for breeding.

Once Hydrophylax malabaricus was found abundantly in the Western Ghats of India, but Padhye et al. (2002) and Chandra \& Gajbe (2005) report the populations of this species had declined from several urbanized areas of the same zone. Consequently, the species was kept under "NR" (near threatened) status. The day by day increasing anthropogenic pressure inside the subterranean caves could be a big threat to the hypogean populations of this frog. However, it is still found in numerous protected areas and is already protected by national legislation (http://www.iucnredlist.org/details/58657/o ).

\section{Ranidae: Ranixalinae: \\ Indiranaleithii Boulenger, 1888}

Indirana leithii is commonly referred as Leith's leaping frog or Matheran Indian frog. A strong glandular fold beneath the eye to the shoulder is the most striking identifying characteristic for this particular species (Fig. 3). High variation in body colours can be seen even in a single group of this species, some being dark grey to black others are yellowish to pink; golden patches are also apparent dorsally in some specimens

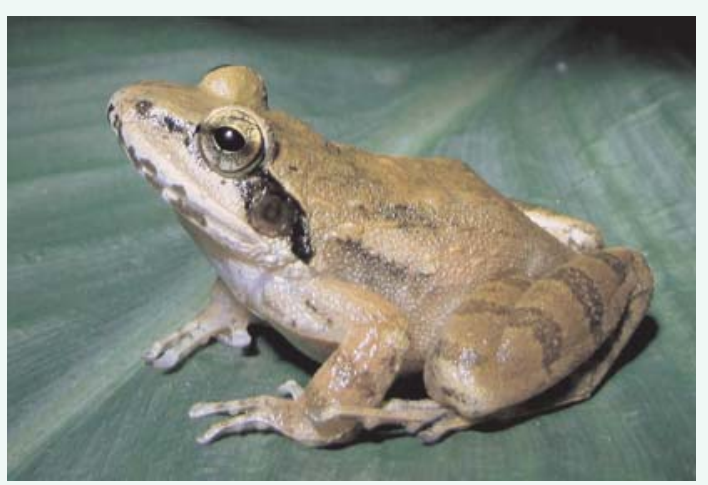

Fig. 3: Indirana leithii (Abdulali \& Daniel, 1954). It is highly sensitive to any type of disturbance, takes many jumps to hide itself whenever it is threatened (McCann, 1935). It is a very common inhabitant of Kanheri and Karla caves of Western Ghats (McCann, 1935; 1946b; Abdulali \& Daniel, 1954, Daniel \& Sekar, 1989; Sekar, 1992). Besides the Western Ghats reports are also available suppoting the existence of this frog from Andhra Pradesh, the region of Eastern Ghats, India (Srinivasulu \& Srinivasulu, 2008; Srinivasulu \& Das, 2008), and some parts of Central India (Chandra \& Gajbe, 2005) but doubt has been raised regarding the authenticity of such records for Leith's frog, occurring outside the range of Western Ghats (Biju et al., 2004).

During rain it could be seen in the epigean environmental conditions and is crepuscular (McCann, 1946b). Indirana leithii could easily be confused with $I$. beddomii, which is also sometimes found inside caves. Interestingly, I. beddomii is a common resident of Robber Cave of the Western Ghats. Indirana leithii is currently classified as "Vulnerable" (http://www.iucnredlist.org/details/58311/o).

\section{Ranidae: Nyctibatrachinae}

Nyctibatrachushussaini Krishnamurthy et al., 2001

Synonyms: 


\section{Nyctibatrachus karnatakaensis Dinesh etal., 2009.}

Nyctibatrachus hussaini belongs to a Night Frog group; Nyctibatrachus Boulenger, this genus represents nocturnal frogs, an important prerequisite trait for cave life. The holotype of this species was discovered from a cave of the Kudremukh National Park (altitude: 850-1110 $\mathrm{m} \mathrm{msl)}$ of the Western Ghats. However, due to some technical shortcomings (Dinesh et al., 2008) the same was re-described under the name Nyctibatrachus karnatakaensis Dinesh et al., 2007. The adult differs from other members of the group by having a large body size, apparent corrugated textured skin on the body surface and limbs, and complete webbing of the feet.

Nyctibatrachus hussaini could be easily confused by another troglophilic species, $N$. humayuni which could also be sympatric with a few other frog species in the Robbers and other adjacent caves and crevices of the Western Ghats. Though this frog has been recently highlighted, its distribution range is still uncertain. In view of the extent of occurrence in an area less than 5,00o km2 and the area of occupancy less than 500 km2 (e.g., Kudremukh National Park) in the present status, it has been listed as an Endangered species (http://www.iucnredlist.org/details/58399/o).

The Kudremukh National Park is mainly threatened by mining activities, and the harvesting of wood and timber by the local people. The high level of urbanization of the area is also a major threat factor for this particular cave frog.

\section{Ranidae: Micrixalinae}

\section{Micrixalus spelunca Bijuetal., 2014}

This is also a newly described frogs from India, commonly referred as the Cave Dancing Frog. The word spelunca derived from Latin word, means "cave." Indeed it was first recorded froma damp cave of southern part of the Western Ghats (locality Coonoor; district Nilgiris; state Tamil Nadu). In appearance, it is small sized, uniform dark brown with light brown reticulations throughout the dorsum, foot blackish-grey, very short web in the hind limbs, and glandular finger tips.

In 2014, Biju et al., (2014) reported fourteen new species of Micrixalus frogs which were discovered from the mountainous tropical forests of the Western Ghats. All the new members of this genus are collectively referred as "dancing frogs". This particular behavior is suspected only due to the unusual courtship behavior of the males. During mating season, the males make unique leg movements and wave their hind legs in a display called "footflagging" when trying to attract mates (Biju et al., 2014).

The recognition of 14 species of the genus is an outcome of multiple mitochondrial gene (16S and COI) barcoding, which is a unique molecular tool to scrutinize high level species diversity. However, morphologically this particular frog is very close to some other members of the dancing frog group: M. candidus, M.elegans, M.kurichiyari, M. niluvasei, M. sairandhri and M. Uttaraghati, (Biju et al., 2014). Micrixalus spelunca is endemic to India. Though, it is a newly discovered frog of India, it will be too early to designate it any IUCN status. 


\section{Cave Frogs from Jaintia Hill, Meghalaya:}

Meghalaya is situated in the far northeast of India along the northern border of Bangladesh. Much of the Meghalaya is of hilly plateaus which reach altitudes over $1000 \mathrm{~m}$. Along the southern and eastern margins of the plateau are large bands of limestone interstratif ied with sandstone beds (200 km long and $30 \mathrm{~km}$ wide). This state experiences some of the world's highest recorded rainfall, causing dissolution of limestone deposition. Various world class cave formation takes place in this region. Each cave also harbors a large variety of cave organisms (Harries et al., 2008). It was a report by Harries et al., (2008) that first stated the occurrences of frogs in various caves of Meghalaya. Further, Biswas \& Harries (2011) identified the most common cave frog populating the caves of Jaintia Hill as Odorrana chloronota.

\section{Ranidae: Raninae}

\section{Odorrana chloronota Günther, 1875}

Synonyms:

Polypedates chloronotus Günther, 1876

Huia chloronota

Günther, 1875

Rana chloronota

Günther, 1875

This frog is commonly referred to as Chloronate huia frog or Copper-cheeked frog, and it is easily noticed inside the various caves of Jaintia Hill. It is the only species mentioned in this report that is not an endemic species for India. In India its distribution is restricted to the northeastern part,

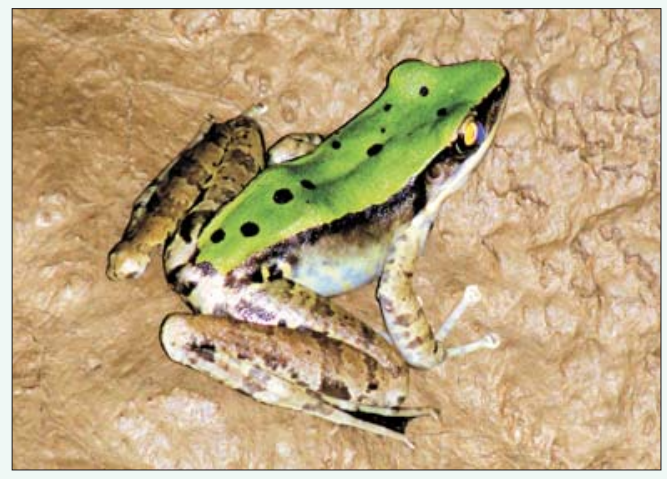

Fig. 4: Odorrana chloronota adjacent to southeast Asian countries where it is abundant (Biswas \& Harries, 2011). The taxon ranges from northeastern India (West Bengal, Assam, Meghalaya, Nagaland, Manipur and Mizoram), Nepal, Bangladesh Myanmar, Thailand, Cambodia, Laos and much of Viet Nam, to central and southern China. (https://aark.portal.isis.org/Lists/Cambodia/DispForm.aspx?ID=49).

Characteristic features include a spectacular vivid green dorsal colour and a peculiar odoriferous skin secretion containing chemicals having anti-bacterial properties (Fig. 4). The frogs also produce sub-sonic sounds (Johnson, 2008). This frog has not quickly responded to any disturbance. Epigean populations are known to be nocturnal and occur in wet habitats, near to river streams.

Random mining and extraction in the mountainous areas of the complete state Meghalaya are not only accelerating the extinction of this species from the area, but it is threatening the other cavernicolous species of the area (Biswas, 2009).

\section{Discussion:}

The basic ecological requirements for most of the frogs are high relative humidity, alkalinity, $\mathrm{CO}_{2}$ and higher dissolved oxygen (DO), infrequent air movement, low ambient noise levels, 
and less fluctuation in air, water and soil temperature, which always form the basic environment of every subterranean cave. Nevertheless, to successfully establish a population inside any natural subterranean cave the frog must be able to physiologically cope with the perpetual darkness; the frog must be pre-adapted to dwell in such conditions. The cave frogs described above are all basically nocturnal anurans, and the webs between toes and the glandular fingertips testify that the frogs are petricolous and well adapted for movement in rocky places. There are other reports on various other frog species which have been infrequently observed in various caves of the Indian sub-continents but those are either accidental visitors or highly opportunistic species restricted to only the twilight zones of the caves.

In India, the greatest number of caves exist in Western Ghats and North-Eastern Valleys of Meghalaya. In addition some parts of Eastern Valleys and Central India also have large subterranean passages (caves), but most of the cavernicolous frogs are from Western Ghats. As per Aravind \& Gururaja (2011), the geophysical, ecological and evolutionary history of Western Ghats and associated adaptive radiations in amphibians, especially frogs determine the present amphibian dispersion in the region. Bossuyt \& Milinkovitch (2001) stressed that three lineages of Western Ghats amphibians (members of frog families Micrixalidae, Nyctibatrachidae and Ranixalidae), which are endemic to the Western Ghats and have not been found in any other part of the Indian sub-continent, should be considered Gondwan relicts. Nevertheless, the caves of other parts of the Indian subcontinent are dominated only by the members of the family Ranidae (Biswas, 2010; Biswas \& Shrotriya, 2011; Biswas \& Harries, 2011). Further, the bioinventory is only possible in caves which are accessible to us. Nevertheless, there are various caves existing which connect to the external world through small crevices from where the entry/exit of only small animals is possible. The existences of various known and unknown species in such caves could not be ruled out.

Fortunately, most of the cave frogs of India are found in the protected areas and most are further protected by Indian national legislation. But due to mining and quarrying the caves of the state Meghalaya are under serious threat and thus the complete subterranean biodiversity is also in peril. Increasing urbanization and the random exploitation of the wild caves in the name of ecotourism are also major factors for depletion of the frog populations from the caves.

Apart from the above named threats, the disease chytridiomycosis, caused by the fungus Batrachochytrium dendrobatidis (Bd), has become a major factor for numerous amphibian extinctions in Central, South, and North America, Australia and Europe (Whittaker \& Vredenburg 2014). Among the Indian cave frogs this disease was reported in Odoranna chloronota (Swei et al., 2011) and Indirana leithii (Dhanukar et al., 2013). Various research is under way to eradicate the fungus Batrachochytrium dendrobatidis and to protect the rare species of frogs. 


\section{Acknowledgements:}

I am thankful to Mr. Wilfredo Falcón-Linero of University of Puerto Rico at Humacao for permitting me to use his photographs of Eleutherodactylus cooki (Fig. 1a,b) and Mr. Vishal Prasad (wildlife researcher \& conservation photographer) for permitting me to use his photograph of Indirana leithii (fig. 3 ) in this manuscript. .

\section{References:}

Abdulali, H. \& Daniel, J. C. (1954): Distribution of Rana leithii Boulenger a correction. J. Bom. Nat. Hist. Soc., 52: 635-636.

Aravind N.A., Ganeshaiah K.N. \& Uma Shaanker. R. (2004): Croak, croak, croak: Are there more frogs to be discovered in Western Ghats? Curr. Sci. India, 86: 1471-1472.

Aravind N.A. \& Gururaja K.V. (2011): Amphibians of the Western Ghats. Commissioned paper for Western Ghats Ecology Expert Panel, MoEF.

Barrio-amoros C.L. (2006): A new dendrobatid frog (Anura: Dendrobatidae: Colostethus) from Apeada tepui, southern Venezuela. Zootaxa, 1110:59-68.

Beard K.H., McCullough S. \& Eschtruth A.K. (2003): Quantitative Assessment of Habitat Preferences for the Puerto Rican Terrestrial Frog, Eleutherodactylus coqui._. Herpetol., 37(1):10-17

Biju S.D. \& Bossuyt F. (2003): New frog family from India reveals an ancient biogeographical link with the Seychelles. Nature, 425:711-714.

Biju S.D., Dutta S.K., Padhye A. \& Inger R.F. (2004): Indirana leithii IUCN Red list of threatened species. Ver.- 2011.1

Biju S.D., Van Bocxlaer I., Mahony S., Dinesh K.P., Radhakrishnan C., Zachariah A., Giri V.B., \& Bossuyt F. (2011): A taxonomic review of the Night Frog genus Nyctibatrachus Boulenger, 1882 in the Western Ghats, India (Anura: Nyctibatrachidae) with description of twelve new species. Zootaxa 3029:1-96.

Biju S.D., Sonali G., Gururaja K.V., Yogesh S.\& Sandeep A.W. (2014): DNA barcoding reveals unprecedented diversity in Dancing Frogs of India (Micrixalidae, Micrixalus): a taxonomic revision with description of 14 new species. Ceylon Lournal of Science (Biol. Sci.), 43(1) http://dx.doi.org/10.4038/cjsbs.v43i1.6850

Biswas J. (2009): The biodiversity of Krem Mawkhyrdop of Meghalaya, India, on the verge of extinction. Curr. Sci., India, $96(7): 904-910$

Biswas J (2010): Kotumsar Cave biodiversity: a review of cavernicoles and their troglobiotic traits. Biodivers. Conserv., 19 (1), 275-289.

Biswas J. \& Shrotriya S. (2011): Dandak: a mammalian dominated cave ecosystem of India. Subterranean Biology, 8, $1-8$

Biswas J. \& Harries , D.B. (2011): Krem Bylliat: The Harbour of Precedent Cavernicolous Representatives from the Jaintia Hills, Meghalaya. India. I. Biol. Sci. , 11 (7):459-465

Black J.H. (1973): A checklist of the cave fauna of Oklahoma: Amphibia. Proceedings of the Oklahoma Academy of Science, 53:33-37

Bossuyt F. \& Milinkovitch M.C. (2001): Amphibians as Indicators of Early Tertiary 'Out of India' Dispersal of Vertebrates. Science, 292: 93-95

Chandra K. \& Gajbe P.U. (2005): An inventory of herpetofauna of Madhya Pradesh and Chhattisgarh. Zoos' $\underline{\text { Print }}$ Journal, 20(3): 1812-1819

Chari V.K., (1962): A description of the hitherto undescribed tadpole of, and some field notes on the fungoid frog, Rana malabarica Bibron.J. Bom. Nat. Hist. Soc.,2, 59(1):71-76.

Daniel J.C. \& Sekar A. (1989): Field guide to the amphibians of western India. Part 4. L. Bom. Nat. Hist. Soc., 86: 194202.

Dahanukar N., Krutha K., Paingankar M.S., Padhye A.D., Modak N. \& Molur S. (2013): Endemic Asian Chytrid Strain Infection in Threatened and Endemic Anurans of the Northern Western Ghats, India. PLoS ONE, 8(10): e77528-pp. 1-8 
Dinesh K.P., Radhakrishnan C., Reddy M.A.H. \& Gururaja K.V. (2007): Nyctibatrachus karnatakaensis nom. nov., a replacement name for the giant wrinkled frog from the Western Ghats. Curr. Sci. India, 93(2):246250.

Dinesh K.P., Radhakrishnan C., Reddy M.A.H. \& Gururaja K.V. (2008): Taxonomic reasoning: The case of giant wrinkled frog. Curr. Sci. $\underline{\text { India, } 94(8): 965-966}$

Elliott W.R. (2007):Zoogeography and biodiversity of Missouri caves and karst. J. Cave Karst Stud., 69(1): 135-162.

Grismer L.L., Grismer J.L. \& Youmans T.M. (2004): A new species of Leptolalax (Anura: Megophryidae) from Pulau Tioman, West Malaysia. Asiatic Herpetological Research. 10: 8-11.

Gunn J. (2004): Encyclopedia of karst and caves. Fitzroy Dearborn, Chicago and London, PA. p. 1970

Harries D.B., Ware F.J., Fischer C.W., Biswas J. \& Kharpran-Daly B.D. (2008): A review of the biospeleology of Meghalaya, India. L. Cave Karst Stud.,70(3):163-176

Inger R.F. (1999): Distribution of amphibians in South Asia and adjacent islands. In: Duellman, W.E. (Ed.) Patterns of Distribution of Amphibians, a Global Perspective. The Johns Hawkins University Press, London, pp. 445-482.

Johnson K. (2008): Species prioritization - Hong Kong and Guangdon provinces: Rana chloronota, In: Amphibian Ark. https://aark.portal.isis.org/ (accessed on 30/o8/2014).

McCann C. (1935): Occurrence of Leith's frog (Rana leithii Bouleng.) in Salsette Island. J. Bom. Nat. Hist. Soc., 37,3

McCann C.(1946a): Strong odour emitted by the fungoid frog (Rana malabarica) .J. Bom. Nat. Hist. Soc., 46(2): 406.

McCann, C. (1946b): The distribution of Rana leithii Boulenger. J. Bom. Nat. Hist. Soc., 46,2

Myers N., Mittermeier R.A., Mittermeier C.G., da Fonseca G.A.B. \& Kent J. (200o): Biodiversity hotspots for conservation priorities. Nature, 403: 853-858

Padhye A.D., Mahabaleshwarkar M. \& Ghate H.V. (2002): An overview of Amphibian fauna of Pune district with special reference to their status in and around Pune city. Zoos' Print Journal. 17(4): 757-763.

Roelants K., Jiang J \& Bossuyt F. (2004): Endemic ranid (Amphibia: Anura) genera in southern mountain ranges of the Indian subcontinent represent ancient frog lineages: evidence from molecular data. Mol. $\underline{\text { Phylogenet. Evol., }}$ 31: 730-740

Rogowitz G.L., Candelaria C.L., Denizard L.E. \& Melendez L.J. (2001): Seasonal Reproduction of a Neotropical Frog, the Cave Coqui (Eleutherodactylus cooki). Copeia, 2:542-547.

Sekar A.G.(1992): Morphometry, habitat, behaviour \& food of the tadpoles of Leith's frog Rana leithii. L. Bom. Nat. Hist. Soc., 89:259-261.

Srinivasulu C. \& Das, I. (2008): The herpetofauna of Nal lamala hills, Eastern Ghats, India: annotated checklist, with remarks on nomenclature, taxonomy, habitat use, adaptive types and biogeography. Asiatic Herpetological Research, 11:110-131.

Srinivasulu C. \& Srinivasulu B. 2008: Nallamala hills, Andhra Pradesh: a biodiversity conservation priority area in southeastern India. Curr. Sci., India, 95: 703-704

Swei A., Rowley J.J.L.; Rödder D., Diesmos M.L.L.; Diesmos A.C., Briggs C.J., Brown R., Cao T.T.; Cheng T.L.; Chong R.A., Han B., Hero Jm., Hoang H.D., Kusrini M.D., Le Duong T.T., McGuire J.A., Meegaskumbura M., Min Ms., Mulcahy D.G., Neang T., Phimmachak S., Rao Dq., Reeder N.M., Schoville S.D., Sivongxay Ni., Srei N., Stöck M., Stuart B.L., Torres L.S., Dao T.A.A., Tunstall T.S., Vieites D. \& Vredenburg V.T.(2011): Is Chytridiomycosis an Emerging Infectious Disease in. $\underline{P L O S} \underline{O N E,}$ 6(8): e23179-pp. 1-9

Vandel A. (1965): Biospeleology: the biology of cavernicolous animals. Pergamon Press, Oxford, PA p 524.

Withers P.C. \& Edward D.H. (1997): Terrestrial fauna of granite outcrops in Western Australia. Journal of the Royal Society of Western Australia, 80:159-166.

Whittaker K \& Vredenburg V. (2014): AmphibiaWeb: Information on amphibian biology and conservation. Berkeley, California:AmphibiaWeb. Available: http://amphibiaweb.org/. (Accessed:30/o8/ 2014). 